\title{
Genomic Damage in Human Sperm Cells Exposed In Vitro to Environmental Pollutants
}

\author{
Lucia Rocco ${ }^{1,2 *}$, Carmela Peluso ${ }^{1}$, Fulvio Cesaroni ${ }^{3}$, Natascia Morra ${ }^{1}$, Daniela Cesaroni ${ }^{1}$ and Vincenzo Stingo ${ }^{1,2}$
}

${ }^{1}$ Department of Life Sciences, Second University of Naples, SUNFert Laboratory, Caserta, Italy

${ }^{2}$ IC-REACH, Interuniversitary Center Reach, University of Naples, Italy

${ }^{3} A O R N$ “Sant'Anna e San Sebastiano", Caserta, Italy

\begin{abstract}
Environmental pollution of waters caused by the release of chemical substances is becoming a threat for both man and the environment. The active pharmacological agents discharged into the waters, can interact with the cell DNA and induce genetic damage. The aim of the present work was to evaluate the potential genotoxic effects of nine pharmacological agents, Atorvastatin, Sildenafil citrate, Gemfibrozil, Ibuprofen, Atenolol, Ofloxacin, Carbamazepine, Bezafibrate, and Diclofenac present in the waste waters of some Italian treatment plants. Genotoxic effects of the nine pharmacological compounds were evaluated by using four tests, the Comet Assay, the Diffusion Assay, the TUNEL test, and RAPD-PCR technique. The sperm cells were exposed in vitro for three different times: 15, 30 and 45 min at the mean concentrations detected in the waste waters. All drugs tested induced a statistically significant reduction in the integrity of sperm DNA and high fragmentation values. The drugs found in the wastewater were then able to induce damage to sperm DNA, highlighted in a very early stage of cell suffering, even before they are capable of inducing other metabolic disorders.
\end{abstract}

Keywords: DNA damage; Comet assay; Tunel test; RAPD-PCR; Male; Fertility; Environment

\section{Introduction}

Over the last few years the pathologies of the male reproductive system have had a notable social interest. In fact they have caused an increase in infertility, as well as infantile malformations and spontaneous abortions [1]. Endogenous factors are defects in spermiogenesis caused by an incorrect repair of DNA filaments generated during the process of chromatin remodeling, by damage induced by excessive levels of oxygen reactive species and by an apoptotic process of DNA degradation that is similar to that seen in somatic cells [2]. Moreover, exogenous or environmental factors have been associated with a significant change in sperm parameters (concentration, motility, cellular morphology) and increased levels of spermatic DNA fragmentation; genotoxic agents, including drugs, compromise the integrity of genetic material and influence DNA expression, both directly and indirectly [3].

Notwithstanding the fact that the large selection of pharmacological molecules has improved the health of individual humans and/or animals, they have also caused a notable damage to the environment due to their high reactivity.

Pharmacological substances, incorrectly disposed of, can reach water treatment plants in large quantities and, if not degraded, can be released into the waters of seas, lakes and rivers [4].

Over the last few years in Italy, studies have been carried out on monitoring pharmacological substances and hormones in the waters of six treatment plants (STPs) [5] and the substances that were most frequently found were anti-bacterials, anti-inflammatories and lipid regulators.

Again in Italy, other studies have been carried out to evaluate the presence of pharmacological substances in superficial waters and waters for human consumption $[4,6,7]$. Furthermore, in the effluents of council water treatment plants the analyses carried out showed the presence of a mixture of different pharmacological substances [8].

In this paper we have evaluated the genotoxic potential of nine pharmacological substances: Diclofenac, Carbamazepine, Gemfibrozil, Sildenafil citrate, Bezafibrate, Atenolol, Ofloxacin, Atorvastatin and Ibuprofen to concentration found in the environment (Table 1).

In vitro toxicity screening using animal sperm has been developed over the last decade $[9,10]$. The large number of cells isolated from animals facilitates designing experiments to assess both the toxicity of compounds to which subjects could be exposed and the reproductive risk. Because sperm motion is important for sperm functional capacity [11], not only the percentage of motile spermatozoa but also sperm movement characteristics might give information regarding quantitative and qualitative evaluation of toxic effects of chemicals [12].

\section{Methods}

\section{Sperm preparation and incubation procedure}

Forty semen samples were obtained from men aged between 20 and 30 years, referred to our Biology of Reproduction Laboratory at the Department of Life Sciences (Second University of Naples) either for routine semen analysis before in vitro fertilization or for semen analysis screening. The ejaculates were collected by masturbation after a recommended sexual abstinence of 2-3 days. Immediately after liquefaction (about 30 minutes at $37^{\circ} \mathrm{C}$ ) sperm parameters were determined according to the WHO guidelines [13] and surplus semen, were used for successive experimental analysis.

*Corresponding author: Lucia Rocco, SUNFert, Second University of Naples Department of Life Sciences, Via Vivaldi 43, 81100, Caserta, Italy, Tel: +39 0823274555; Fax: +39 0823274571; E-mail: lucia.rocco@unina2.it

Received September 21, 2011; Accepted January 10, 2012; Published January 12, 2012

Citation: Rocco L, Peluso C, Cesaroni F, Morra N, Cesaroni D, et al. (2012) Genomic Damage in Human Sperm Cells Exposed In Vitro to Environmental Pollutants. J Environment Analytic Toxicol 2:117. doi:10.4172/2161-0525.1000117

Copyright: ( 2012 Rocco L, et al. This is an open-access article distributed unde the terms of the Creative Commons Attribution License, which permits unrestricted use, distribution, and reproduction in any medium, provided the original author and source are credited. 
Seminal liquid was suspended in PBS-BSA 1X (Saline Phosphate Buffer with Bovine Serum Albumine - SIGMA P3688), in a quantity proportional to its volume, mixed and centrifuged at $2000 \mathrm{rpm}$ for 15 min. The supernatant was eliminated and the pellet re-suspended in PBS $1 X$ (taking the volume to $10 \mathrm{ml}$ ) and then mixed. Then the sample was divided into five test tubes ( $2 \mathrm{ml}$ for each tube):

- One containing only the sample (negative control at time 0 of incubation for each set of drug) to evaluate the possible individual polymorphisms;

- One containing benzene, a well-known genotoxic agent and thus used as positive control [14] at a concentration of $4 \mu \mathrm{l} / 10 \mathrm{ml}$;

- The other three tubes contained each pharmacological substance to be tested exposed for three different times: 15,30 and 45 min.

Incubation was performed in MEM (Modified Earle Medium) at $37^{\circ} \mathrm{C}$. After treatment the samples were centrifuged at $2000 \mathrm{rpm}$ for 15 min, the supernatant was eliminated and the pellet was re-suspended in $500 \mu \mathrm{l}$ PBS 1X. The DNA damage was then evaluated using the Comet Assay, the Diffusion Assay, the TUNEL Test and RAPD-PCR.

\section{The comet assay and the diffusion assay}

The Comet Assay technique quantifies the damage to genetic material and also the eventual degree of repair to both eukaryotic and prokaryotic cells $[15,16]$. For this reason it is used for the study of the effects caused by both endogenous and exogenous genotoxic agents on genetic material, evaluating damage of various types (mutations or breaks) to the DNA [17-19].

The test is based on the principle that a broken filament of supercoiled double-strand DNA undergoes a reduction in its size and can thus be used for electrophoresis. Using highly alkaline experimental conditions there is a denaturing of the DNA, an un-coiling of the double-strand and the expression of unstable alkaline sites in the form of single broken filaments. Therefore, following cell lysis and treatment with an alkaline solution, the denatured DNA, exposed to an electric field, is able to migrate; thus, the cells with DNA damage appear like comets, where the tail is the fragmented DNA, while the control cells show a more spherical and condensed nucleus.

We withdrew about $15 \mu \mathrm{l}$ of the spermatozoa suspension from the tubes containing the samples and mixed them with $65 \mu$ of Low Melting Point (LMP) Agarose at $0.7 \%$. Glass slides treated with Normal Melting Point (NMP) Agarose at $1 \%$ were used to receive $85 \mu$ of the mixture previously prepared and covered with a cover glass and kept at $4^{\circ} \mathrm{C}$ for $30 \mathrm{~min}$ to solidify the agarose. The coverglasses were removed and $100 \mu \mathrm{l}$ of LMP agarose, at $0.7 \%$ at $37^{\circ} \mathrm{C}$, were added and kept for another $30 \mathrm{~min}$ at $4^{\circ} \mathrm{C}$.

Once the agarose had solidified the slides were immersed and maintained at $4^{\circ} \mathrm{C}$ for $60 \mathrm{~min}$ in cold Lysis buffer $\left(\mathrm{NaCl} 2.5 \mathrm{M}, \mathrm{Na}_{4} \mathrm{EDTA}\right.$ $100 \mathrm{mM}$, Tris-Base $10 \mathrm{mM}$, Triton-X100 1\% and DMSO 1\%) at $\mathrm{pH}$ 10.0 , and kept in the dark to avoid light induced damage. The slides were then washed with a neutralizing solution made up of Tris- $\mathrm{HCl} 0.4$ $\mathrm{M}$ at $\mathrm{pH}$ 7.5. The slides were then air dried and underwent digestion with proteinase K O.N. ( $\mathrm{NaCl} 2.5 \mathrm{M}$, Tris-base $5 \mathrm{mM}$, DMSO $0.05 \%$ and proteinase $\mathrm{K} 50 \mu \mathrm{g} / \mathrm{L}$ ). The following day the slides were washed again with neutralizing solution. The slides were then incubated for $10 \mathrm{~min}$ at room temperature in electrophoresis buffer $(\mathrm{NaOH} 0.6 \mathrm{M}$ and $\mathrm{Na}_{2}$ EDTA $50 \mathrm{mM}$ ) and then underwent electrophoresis $(25 \mathrm{~min}$ at $300 \mathrm{~mA}$ ). The slides were then washed three times at 5 min intervals with the neutralizing solution. As a final step the slides were fixed in methanol for $5 \mathrm{~min}$ and air dried. The slides were then stained with $100 \mu \mathrm{l}$ of ethidium bromide $(10 \mu \mathrm{g} / \mathrm{ml})$ and read at the fluorescence microscope (Nikon Eclipse E-600) equipped with BP 515-560 nm and LP $580 \mathrm{~nm}$ filters. For each sample two slides were read giving a total of 100 cells. The images were acquired and analyzed using software for image analysis (Komet version 6.0.0, Kinetic Imaging). The parameter considered was the percentage of damaged DNA present in the tail of the comet (tail DNA). Statistical significance was also evaluated.

The Diffusion Assay is a modified version of the Comet Assay. It includes the same experimental steps with the only exception of electrophoresis and the enzymatic treatment with proteinase K.

This method estimates the degree of apoptosis of isolated cells [20]. The nuclei of the apoptotic cells are characterized by having a highly dispersed DNA and thus have an irregular shape. The cells with damaged DNA have larger nuclei with internucleosomal DNA.

\section{Statistical analysis}

Differences in the percentage of DNA fragmentation among the experimental points in the semen were analyzed by multifactorial analysis of variance (MANOVA). We have considered statistically significant differences between means with a $\mathrm{p}$-value $\leq 0.05$.

\section{TUNEL test}

This test is used to detect the anomalies of spermatic chromatin. In fact, there is a correlation between the percentage of fragmented DNA of the spermatozoa and motility, morphology and the concentration of the ejaculate [21].

The TUNEL test (Terminal deoxynucleotidyl transferase UTPdriven Nick End Labeling) detects in the seminal liquid the sperm that have a breakage in the DNA chain [22]. This test has two advantages: the intensity of the staining and the rapid incorporation of the nucleotides.

The TUNEL test was carried out on our samples using the "In Situ Cell Death Detection Kit" (Roche Diagnostics), in which the marker used is Fluorescein Isothiocyanate (FITC). The nuclei of the spermatozoa with double-strand DNA breaks appear green, while those with whole DNA have no color. For this reason, we applied a contrast fluorochrome DAPI showing the sperm with whole DNA in blue so that they were easily distinguishable from the sperm with the altered DNA. For each control and treatment two slides were read giving a total of 150 cells per slide. The slides were read by using a fluorescence microscope (Nikon Eclipse E-600) equipped with BP 330-380 nm and LP $420 \mathrm{~nm}$ filters.

\section{Genomic DNA extraction and RAPD analysis}

Total DNA from spermatic cells was extracted and purified using the PureLink Genomic DNA Kit (Invitrogen, Carlsbad, CA) according to the manufacturer's instructions. Two arbitrary primers (SIGMA) were used for RAPD analysis (F1: 5'-ACCGCGAAGG-3' and D11: 5'-GTCCCGACGA-3') [23].

The RAPD method is a PCR-based technique that amplifies random DNA fragments with the use of single short primers of arbitrary nucleotide sequence under low annealing conditions. The technique has been extensively used for species classification and strain determination. Recently, the RAPD assay was also applied to detect genetic instability in tumors [24] and successfully detected genomic 
DNA alterations induced by several DNA-damaging agents, such as benzo[a]pyrene [25,26], heavy metals [27], UV radiation [28] and [29] or X-rays and radio nuclides [30].

The PCR amplifications were performed in $25 \mu \mathrm{l}$ of reaction mixture containing $25 \mathrm{ng}$ of DNA, $1 \mu \mathrm{l}$ of $5 \mathrm{pmol}$ random primer and puRe Taq Ready-To-Go PCR Beads (GE Healthcare, UK). The PCR conditions were as follows: denaturing at $94^{\circ} \mathrm{C}$ for $5 \mathrm{sec}$, annealing at $36^{\circ} \mathrm{C}$ for 1 min (primer D11) and at $46^{\circ} \mathrm{C}$ (primer F1), and extension at $72^{\circ} \mathrm{C}$ for 1 min. The products ( $15 \mu \mathrm{l} \mathrm{each),} \mathrm{mixed} \mathrm{with} \mathrm{loading} \mathrm{buffer,} \mathrm{were} \mathrm{loaded}$ in $2 \%$ agarose gels and electrophoresed at $100 \mathrm{~V}$ for $1 \mathrm{~h}$. The gels were stained with ethidium bromide and visualized under UV light.

\section{Results}

\section{Sperm analysis}

After incubation with the various pharmacological substances, the sperm suspensions again underwent standard analysis to evaluate if there had been any alterations to the seminal parameters before continuing with the tests.

Bearing in mind the spermiogram made before treatment, it can be affirmed that the only parameter that varied was motility: there was a slight decrease in movement of the sperm after exposure to the pharmacological substances. The decrease was about $7-10 \%$ with respect to the control.

\section{Comet assay}

From the results of this test it was seen that after treatment with Atenolol, Atorvastatin, Ofloxacin, Sildenafil citrate, Gemfibrozil and Ibuprofen the damage to the sperm cells was statistically significant for all the exposure times. Instead, as regards Diclofenac, the statistical significance was seen only after $45 \mathrm{~min}$, while for Bezafibrate the statistical significance was seen after 30 minutes. Carbamazepine didn't produce a statistically significative increase of genomic damage (Table 2 and Figure 1).

\section{Diffusion assay}

The action of Atenolol, Atorvastatin, Ofloxacin and Ibuprofen on the nemaspermic cells showed, with respect to controls, an increase of damage in the samples treated for $30 \mathrm{~min}$, which slightly diminished in the following 45. Instead, the treatment with Sildenafil citrate, Diclofenac, Bezafibrate and Gemfibrozil led to an increased percentage of apoptotic cells up to 45 minutes. The treatment with Carbamazepine produced the same results of Comet Assay (Table 2 and Figure 2).

\section{TUNEL test}

The index of DNA fragmentation found after treatment with pharmacological substances for nemaspermic cells increased for all the drugs up to $45 \mathrm{~min}$; while that found after the exposure of the samples to Sildenafil citrate, Carbamazepine, Diclofenac and Bezafibrate increased up to 30 minutes of treatment with a more or less strong decrease after 45 minutes. DNA fragmentation index after the treatment with carbamazepine were not dissimilar from the control samples (Table 2 and Figure 3).

\section{RAPD-PCR}

The variations of the profile of the RAPD of the samples of DNA treated with the pharmacological substances were compared to the untreated controls. The two primers gave a recognizable profile of bands for the treated samples compared to the untreated ones.
The amplification products obtained by this method showed the presence of numerous bands between 200 and 1300 bp with primer D11 (Figure 4a) and between 500 and 1200 bp with primer F1 (Figure $4 b)$. In particular the negative controls showed bands of $300,350,500$, 550 and 650 for primer D11 while bands of 500, 600, 710, 1300 and 1400 for primer F1.

\section{Discussion}

Various studies present in the literature demonstrate the presence of a mixture of pharmacological substances in waste waters that can interact with the DNA and induce damage to the genetic material more or less severe, such as the break of the double-strand DNA, or induce mutations that can be passed on to successive generations with the consequent increase of biological damage [31,32].

As an experimental model human spermatozoa were used as over the last few years the male genital apparatus has been the subject of numerous studies and papers present in the literature, showing the high vulnerability of this organ for chemical and physical agents, above all in relation to a decrease in fertility (for an accurate review on fragmentation including the aspects on pollution and the effect of pharmacological compounds see [33]).

The results obtained from the four tests used for the evaluation of damage show that the pharmacological substances tested affect the integrity of the spermatic nucleus after only 15 min of exposure with

\begin{tabular}{|l|l|}
\hline Drugs & Concentration (ng/L) \\
\hline Ofloxacin & 50 \\
\hline Diclofenac & 180 \\
\hline Sildenafil Citrate & 26,25 \\
\hline Atenolol & 241 \\
\hline Bezafibrate & 57 \\
\hline Carbamazepine & 310 \\
\hline Atorvastatin & 13 \\
\hline Gemfibrozil & 380 \\
\hline Ibuprofen & 92 \\
\hline
\end{tabular}

Table 1: Pharmacological agents and relative concentrations tested in this study

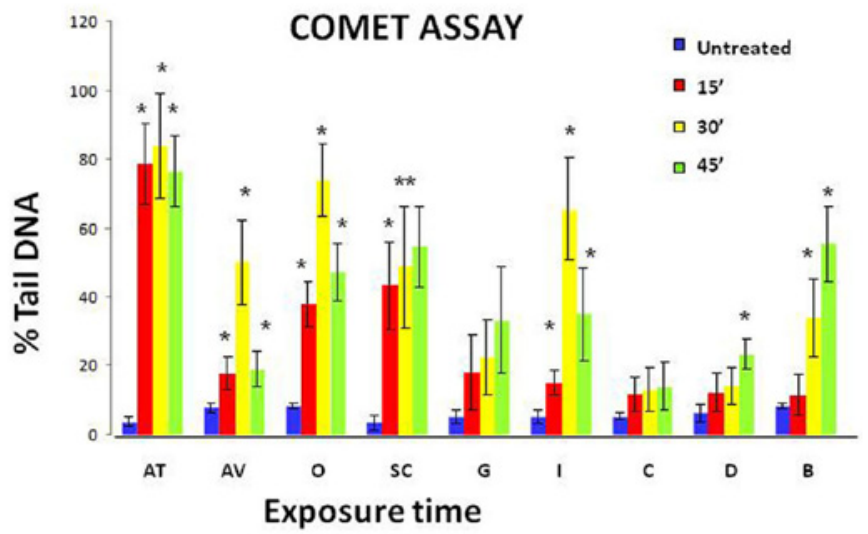

Figure 1: Percentage of sperm DNA damage to different treatment times. $\%$ of DNA in the tail of the comet in sperm (ordinata) after different exposure times (abscissa) to examined pharmacological agents. AT $=$ atenolol: $\mathrm{AV}=$ atorvastatin; $\mathrm{O}=$ ofloxacin; $\mathrm{SC}$ = sildenafil citrate; $\mathrm{G}$ = gemfibrozil; $\mathrm{I}$ = ibuprofen; $\mathrm{C}$ = carbamazepine; $\mathrm{D}=$ diclofenac; $\mathrm{B}=$ bezafibrate. Were considered statistically significant differences between means with a p-value $\leq 0.05\left(^{*}\right)$. The bars represent the standard deviation. 
Citation: Rocco L, Peluso C, Cesaroni F, Morra N, Cesaroni D, et al. (2012) Genomic Damage in Human Sperm Cells Exposed In Vitro to Environmental Pollutants. J Environment Analytic Toxicol 2:117. doi:10.4172/2161-0525.1000117

Page 4 of 7

\begin{tabular}{|c|c|c|c|c|}
\hline Drugs & Exposure Time (min) & $\mathrm{DFI}^{\mathrm{a}}$ & Apoptotic Cells ${ }^{b}$ & DNA Tail \pm SD \\
\hline \multirow{4}{*}{ ATENOLOL } & untreated & 9,71 & 27 & $3,67 \pm 1,37$ \\
\hline & 15 & 26,05 & 39 & $78,54 \pm 11,64$ \\
\hline & 30 & 33,99 & 43 & $83,90 \pm 15,41$ \\
\hline & 45 & 24,60 & 36 & $76,36 \pm 10,38$ \\
\hline \multirow{4}{*}{ ATORVASTATIN } & untreated & 7,00 & 18 & $7,73 \pm 1,40$ \\
\hline & 15 & 57,00 & 63 & $17,64 \pm 4,63$ \\
\hline & 30 & 70,00 & 83 & $49,85 \pm 12,20$ \\
\hline & 45 & 65,00 & 69 & $18,87 \pm 5,21$ \\
\hline \multirow{4}{*}{ OFLOXACIN } & untreated & 12,49 & 12 & $8,31 \pm 0,78$ \\
\hline & 15 & 39,82 & 54 & $37,87 \pm 6,40$ \\
\hline & 30 & 41,90 & 69 & $73,79 \pm 10,26$ \\
\hline & 45 & 40,85 & 67 & $47,23 \pm 8,43$ \\
\hline \multirow{4}{*}{ SILDENAFIL CITRATE } & untreated & 13,33 & 19 & $3,42 \pm 2,17$ \\
\hline & 15 & 33,30 & 31 & $43,30 \pm 12,74$ \\
\hline & 30 & 40,00 & 35 & $48,64 \pm 17,43$ \\
\hline & 45 & 56,66 & 46 & $54,61 \pm 11,65$ \\
\hline \multirow{4}{*}{ GEMFIBROZIL } & untreated & 5,30 & 16 & $4,94 \pm 1,97$ \\
\hline & 15 & 8,96 & 21 & $17,94 \pm 10,71$ \\
\hline & 30 & 10,32 & 35 & $22,38 \pm 11,07$ \\
\hline & 45 & 13,57 & 39 & $33,14 \pm 15,48$ \\
\hline \multirow{4}{*}{ IBUPROFEN } & untreated & 3,31 & 20 & $4,94 \pm 1,97$ \\
\hline & 15 & 6,66 & 49 & $14,93 \pm 3,47$ \\
\hline & 30 & 9,55 & 36 & $65,45 \pm 14,73$ \\
\hline & 45 & 4,05 & 32 & $34,93 \pm 13,63$ \\
\hline \multirow{4}{*}{ CARBAMAZEPINE } & untreated & 11,31 & 19 & $5,18 \pm 1,04$ \\
\hline & 15 & 26,60 & 25 & $11,78 \pm 4,91$ \\
\hline & 30 & 34,37 & 33 & $13,03 \pm 6,32$ \\
\hline & $45^{\prime}$ & 45,49 & 39 & $13,90 \pm 6,90$ \\
\hline \multirow{4}{*}{ DICLOFENAC } & untreated & 13,31 & 19 & $6,17 \pm 2,62$ \\
\hline & 15 & 29,81 & 21 & $12,13 \pm 5,57$ \\
\hline & 30 & 41,89 & 33 & $14,12 \pm 5,34$ \\
\hline & 45 & 46,06 & 42 & $23,35 \pm 4,29$ \\
\hline \multirow{4}{*}{ BEZAFIBRATE } & untreated & 16,66 & 16 & $8,31 \pm 0,78$ \\
\hline & 15 & 20,00 & 21 & $11,51 \pm 5,98$ \\
\hline & 30 & 32,50 & 27 & $33,90 \pm 11,51$ \\
\hline & 45 & 40,85 & 38 & $55,30 \pm 10,87$ \\
\hline
\end{tabular}

aDNA Fragmentation Index expressed in percentage as a result of the TUNEL test

${ }^{b}$ Number of apoptotic cells expressed in percentage as a result of the Diffusion Assay

'DNA present in the tail of the comet expressed in percentage after the COMET Assay

$\mathrm{SD}=$ standard deviation

Table 2: Sperm DNA fragmentation values for each pharmacological compound tested in the present study.

damage being statistically significant with respect to controls, as shown by the computerized elaboration of the values obtained with the Comet Assay.

The reproducibility of the four techniques, which were carried out separately, shows that each of them is sufficient for the analysis of a spermatic population; this indicates that they are very sensitive.

DNA fragmentation is one of the principle causes of male infertility. Various clinical studies indicate that levels of fragmentation of the chromatin above $30 \%$ are associated with no pregnancy or spontaneous abortion [34,35].

The main objective of this research was to examine the effects of nine commonly used drugs to evaluate the alterations of the integrity of human sperm. We use the Comet Assay with electrophoresis in neutral conditions as it is more sensitive to the break of the double-strand of the DNA helix. Numerous publications have used the Comet test to quantify the breakage of the double-strand of the DNA in human sperm [16,36-39] and comparing the damage to the somatic cells with that of the germinal cells it has been shown that sperm exhibit a greater damage [40]; this takes place because mature sperm are unable to repair the damage to their DNA as during spermiogenesis. The spermatic cells, in fact, lose their cytoplasm and the enzymes having a repair function [41-43]. Noteworthy are the advantages of this technique in evidencing the loss of the DNA integrity in sperm cells [44-45].

The TUNEL Test can be used to quantify the breakage of the DNA strands endogenous in nuclear spermatic chromatin [46-47] and today we can say that this technique (due to its sensitivity, specificity, speed and low cost) should be considered the first choice for the evaluation of spermatic DNA breakage, in particular in cases of male infertility.

Therefore it is one of the preferred and most used techniques. The results support the hypothesis that fragmented DNA is the cause for failed conception in many couples. In the TUNEL test a percentage of sperm with DNA fragmentation above $27 \%$ is considered pathological [48].

Very interesting evidences came from the slightly different data 


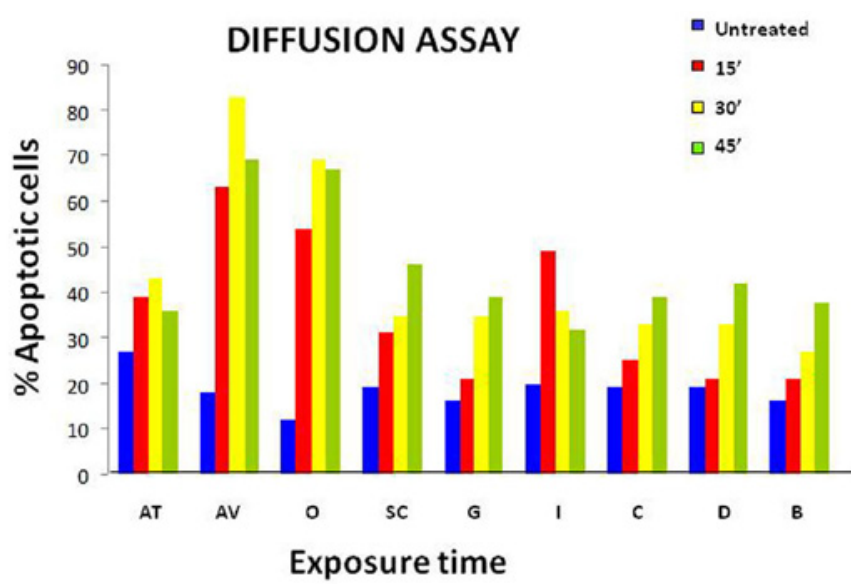

Figure 2: Percentage of sperm apoptotic cells to different treatment times as determined by Diffusion Assay. \% of sperm apoptotic cells (ordinata) after different exposure times (abscissa) to examined pharmacological agents. For drugs abbreviations see Figure1.

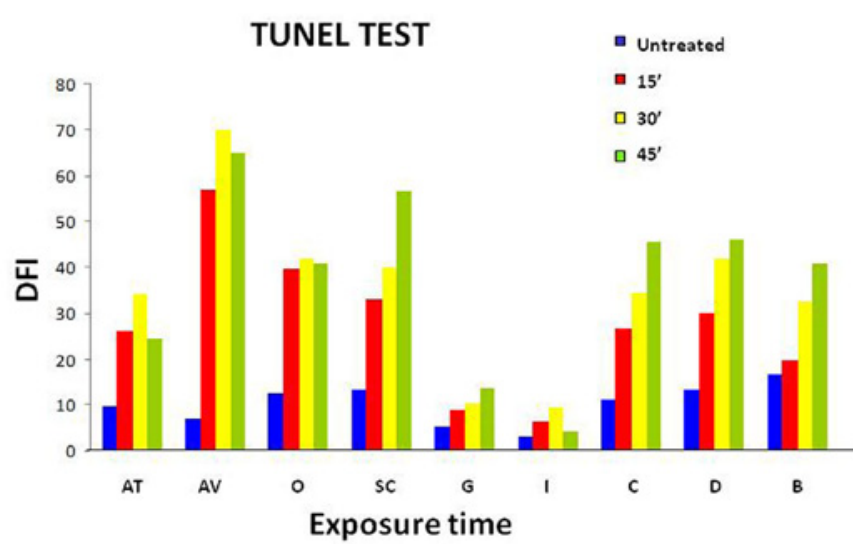

Figure 3: Percentage of sperm DNA fragmentation to different treatment times as determined by TUNEL Test. \% of sperm DNA fragmentation (DFI) (ordinata) after different exposure times (abscissa) to examined pharmacological agents. For drugs abbreviations see Figure1.
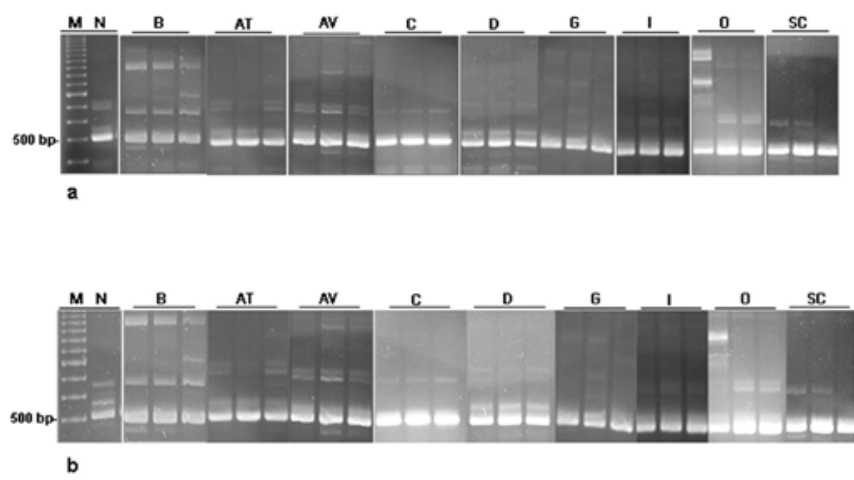

Figure 4: Pattern RAPD-PCR of DNA samples treated with the pharmacological substances. RAPD-PCR fingerprinting of sperm generated by primer D11(a) and F1(b) incubated with the tested drugs for 1530-45 minutes. The appearance and disappearance of bands and intensity variations of the same pattern than the negative control were considered. $\mathrm{M}=$ marker $100 \mathrm{bp} ; \mathrm{N}=$ control. For drugs abbreviations see Figure1. observed in the Diffusion Assay. The increasing of apoptotic degree, allowed us to state that, as observed by several scientists [41-43], in sperm cells with damaged DNA, apoptosis is the only possible option to prevent transmission of imperfect genetic information. We could suppose that the Diffusion Assay is a more sensitive method to detect the apoptotic degree for sperm cells. Recently, it was suggested that aberrant spermatogenesis could lead to alterations in chromatin packaging and a deficiency in protamination which would make sperm DNA more susceptible and vulnerable to a variety of stressors, including environmental factors. In addition, it was hypothesized that activation of caspases and endonucleases could induce sperm DNA fragmentation [49]. Nevertheless, Aitken et al. [50] postulated that the physical architecture of sperm cells could prevent these nucleases from translocating to the nucleus and suggested that DNA fragmentation could result from nonenzymatic reaction or from the action of activated endonuclease already integrated into the chromatin body. The most recent studies on the origin of sperm DNA damage suggested that there might be a cascade of changes that progress from the induction of oxidative stress and oxidized DNA base adduct formation to DNA fragmentation and cell death, that could be better detected by Diffusion Assay technique.

This is the first report of an analysis of genomic alterations in drug-exposed human spermatic cells with the use of RAPD-PCR fingerprinting. These data prove that the RAPD-PCR method is useful for the screening and characterization of genomic regions that have undergone alterations as the result of drug exposure. Changes in the genome that were observed in the present study were mainly variations in RAPD band intensity in the profiles generated by drugexposed cells. These results suggest that short-term (15') drug exposure induces mainly DNA damage, which causes the specific RAPD band intensity to either increase or decrease. Short-term treatment with the pharmaceutical compounds tested did not seem to induce permanent genomic mutations or changes in oligonucleotide priming sites that would mainly produce new, or result in lost, RAPD bands. Several similar findings have been reported by [25] and [51] that used RAPDPCR to analyze the induced DNA damage.

The evidences collected in the present research are in agreement with the results coming from our test performed with some of these drugs on somatic cells. The only differences lie in the time of detection of genotoxic damage, which in the case of sperm cells, are extremely low $[31,32]$.

The results of this work show that the drugs found in the wastewater were able to induce damage to sperm DNA. The concentrations of the pharmacological substances found in waste waters are thus able to induce DNA damage to the nemaspermic cells that can be seen in an early phase of cell suffering (damage to the nucleus), even before it is able to induce more evident metabolic alterations such as a decrease in motility in the case of spermatozoa. DNA fragmentation, in fact, is the first sign of cell suffering that can be triggered in spermatozoa by various stress conditions that accumulate at the intracellular level provoking a cascade of events that lead sperm to apoptosis. We have proposed an approach to assess the exposure of sperm cells to genotoxic substances using biomarkers such as DNA damage, apoptosis and the degree of fragmentation (DFI).

\section{Acknowledgements}

We would like to express our gratitude to Dr. Antony Bridgewood for his assistance in revising the English of this manuscript. We are very grateful to $\mathrm{Dr}$. Ippolita Veronica Valentino and Dr. Elena Cusano for their technical help in the elaboration of diagrams. 
Citation: Rocco L, Peluso C, Cesaroni F, Morra N, Cesaroni D, et al. (2012) Genomic Damage in Human Sperm Cells Exposed In Vitro to Environmental Pollutants. J Environment Analytic Toxicol 2:117. doi:10.4172/2161-0525.1000117

\section{References}

1. Sheiner EK, Sheiner E, Hammel RD, Potashnik G, Carel R (2003) Effect of occupational exposures on male fertility: literature review. Industrial Health 41 : $55-62$.

2. Santiso R, Muriel L, Goyanes V, Segrelles E, Gosálvez J, et al. (2007) Evidence of modified nuclear protein matrix in human spermatozoa with fragmented deoxyribonucleic acid. Fertil Steril 87: 191-194.

3. Shugart L, Theodorakis C (1994) Environmental genotoxicity: probing the underlying mechanism. Environ Health Perspect 12 : 13-17.

4. Castiglioni S, Fanelli R, Calamari D, Bagnati R, Zuccato E (2004) Methodological approaches for studying pharmaceuticals in the environment by comparing predicted and measured concentrations in River Po, Italy. Reg Toxicol Pharmacol 39: 25-32.

5. Castiglioni S, Bagnati R, Fanelli R, Pomati F, Calamari D, et al. (2006) Remova of pharmaceuticals in sewage treatment plants in Italy. Environ Sci Technol 40: $357-363$

6. Zuccato E, Calamari D, Natangelo M, Fanelli R (2000) Presence of therapeutic drugs in the environment. The Lancet 335: 1789-1790.

7. Zuccato E, Castiglioni S, Fanelli R (2005) Identification of the pharmaceuticals for human use contaminating the Italian aquatic environment. J Hazar Mater 122: 205-209.

8. Zuccato E, Castiglioni S, Fanelli R (2006) Pharmaceuticals in the Environment in Italy: Causes, Occurence, Effects and Control. Environ Sci Pollut Res Int 13: $1-21$

9. Rurangwaa E, Biegniewskab A, Slominskac E, Skorkowskib EF, Olleviera F (2002) Effect of tributyltin on adenylate content and enzyme activities of teleos sperm: a biochemical approach to study the mechanisms of toxicant reduced spermatozoa motility. Comp Biochem Physiol C Toxicol Pharmacol 131: 335344.

10. Li ZH, Li P, Dzyuba B, Randak T (2010) Influence of environmental related concentrations of heavy metals on motility parameters and antioxidant responses in sturgeon sperm. Chem Biol Interact 188: 473-477.

11. Larsen L, Scheike T, Jensen TK (2000) Computer-assisted semen analysis parameters as predictor for fertility of men from the general population. The Danish First Pregnancy Planner Study Team. Hum Reprod 15: 1562-1567.

12. Grizard G, Ouchchane L, Roddier H, Artonne C, Sion B, et al. (2007) In vitro alachlor effects on reactive oxygen species generation, motility pattern and apoptosis markers in human spermatozoa. Reprod Toxicol 23: 55-62.

13. World Health Organization (2010) WHO laboratory manual for the Examination and processing of human semen. 5th ed.. Geneva: World Health Organization.

14. Whysner J, Reddy MV, Ross PM, Mohan M, Lax EA (2004) Genotoxicity of benzene and its metabolites. Mutat Res 566: 99-130.

15. McKelvey-Martin VJ, Green MHL, Schmerzer P, Pool-Zobel BL, De Méo MP, et al. (1993) The single cell gel electrophoresis assay (comet assay): a European review. Mutat Res 288: 47-63.

16. Hughes CM, Lewis SEM, McKelvey-Martin VJ, Thompson W (1997) Reproducibility of human sperm DNA measurements using the alkaline single cell gel electrophoresis assay. Mutat Res 374: 261-268.

17. Singh NP, Stephens RE (1998) X-ray induced DNA double-strand breaks in human sperm. Mutagenesis 13: 75-79.

18. Schmid T, Kamischke A, Bollwein H, Nieschlag E, Brinckworth MH (2003) Genetic damage in oligospermic patient detect by fluorescent in-situ hybridization, inverse restriction site mutation assay, sperm chromatin structure assay and the Comet assay. Hum Reprod 18: 1474-1480.

19. Collins AR (2004) The Comet assay for DNA Damage and Repair. Principles, Applications and Limitations. Mol Biotech 26: 249-261.

20. Singh NP (2000) A simple method for accurate estimation of apoptotic cells Exp Cell Res 256: 328-337.

21. Agarwal A, Said TM (2004) Sperm chromatin assessment. In: Textbook of ART. Ed. D.K. Gardner, A. Weissman, C.M. Howles, and Z. Shoham (2nd edn), Taylor \& Francis Group, plc, London, UK pp. 93-106.

22. Gorcyza W, Gang J, Drazynkiewicz Z (1993) Detection of DNA strand breaks in individual apoptotic cells by the in situ terminal deoxynucleotidyl transferase and nick translation assays. Cancer Res 53: 1945-1951.
23. Lee YC, Yang VC, Wang TS (2007) Use of RAPD to detect sodium arseniteinduced DNA damage in human lymphoblastoid cells. Toxicology 239: 108115.

24. Papadopoulos S, Benter T, Anastassiou G, Pape M, Gerhard S, et al. (2002) Assessment of genomic instability in breast cancer and uveal melanoma by random amplified polymorphic DNA analysis. Int J Cancer 99: 193-200.

25. Castano A, Becerril C (2004) In vitro assessment of DNA damage after shortand long-term exposure to benzo[a]pyrene using RAPD and the RTG-2 fish cell line. Mutat Res 552: 141-151.

26. Atienzar FA, Jha AN (2004) The random amplified polymorphic DNA (RAPD) assay to determine DNA alterations, repair and transgenerational effects in B(a)P exposed Daphnia magna. Mutat Res 552: 125-140.

27. Enan MR (2006) Application of random amplified polymorphic DNA (RAPD) to detect the genotoxic effect of heavy metals. Biotechnol Appl Biochem 43: 147-154.

28. Kumar A, Tyagi MB, Jha PN (2004) Evidences showing ultraviolet-B radiationinduced damage of DNA in cyanobacteria and its detection by PCR assay. Biochem Biophys Res Commun 318: 1025-1030

29. Atienzar FA, Cordi B, Donkin ME, Evenden AJ, Jha AN, et al. (2000) Comparison of ultraviolet-induced genotoxicity detected by random amplified polymorphic DNA with chlorophyll fluorescence and growth in a marine macroalgae Palmaria palmata. Aquat Toxicol 50: 1-12.

30. Theodorakis CW, Bickham JW, Lamb T, Medica PA, Lyne TB (2001) Integration of genotoxicity and population genetic analyses in kangaroo rats (Dipodomys merriami) exposed to radionuclide contamination at the Nevada Test Site USA Environ Toxicol Chem 20: 317-326.

31. Rocco L, Frenzilli G, Fusco D, Peluso C, Stingo V (2010) Evaluation of zebrafish DNA integrity after exposure to pharmacological agents present in aquatic environments. Ecotoxicol Environ Saf 73: 1530-1536.

32. Rocco L, Frenzilli G, Zito G, Archimandritis A, Peluso C, et al. (2012) Genotoxic effects in fish induced by pharmacological agents present in the sewage of some Italian water-treatment plants. Environ Toxicol 27: 18-25.

33. Evenson DP (2011) Sperm Chromatin Structure Assay (SCSA): 30 years of experience with the SCSA. pp 125-150. In: Sperm chromatin: biological and clinical applications in male infertility and assisted reproduction. Zini A, Agarwal A (Eds.). Springer Sciences + Business Media, LLC.

34. Larson KL, De Jonge C, Barnes A, Jost L, Everson DP (2000) Relationship between assisted reproductive techniques (ART) outcome and status of chromatin integrity as measured by the Sperm Chromatin Structure Assay (SCSA). Hum Reprod 15: 1717-1722

35. Carrell DT, Liu L, Peterson CM, Jones KP, Hatasaka HH, et al. (2003) Sperm DNA fragmentation is increased in couples with unexplained recurren pregnancy loss. Arch Androl 49: 49-55.

36. Morris ID, llott S, Dixon S, Brison DR (2002) The spectrum of DNA damage in human sperm assessed by single cell gel electrophoresis (comet assay) and its relation ship to fertilization and embryo development. Hum Reprod 17: 990 998

37. Duty SM, Singh NP, Ryan L, Che Z, Lewis C, et al. (2002) Reliability of comet assay in cryopreservad human sperm. Hum Reprod 17: 1274-1280

38. Duty SM, Singh NP, Silva MJ, Barr DB, Brock JW, et al. (2003) The relationship between environmental exposures to phthalates and DNA damage in human sperm using the neutral comet assay. Environ Health Perspect 111: 1164-1169.

39. Van Kooij RJ, De Boer P, De Vreeden-Elbertse JMT, Ganga NA, Singh N et al. (2004) The neutral comet assay detects double strand DNA damage in selected and unselected human spermatozoa of normospermic donor. Intern Androl 27: 140-146.

40. Anderson D, Yu TW, Browne MA (1997) The use of the same image analysis system to detect genetic damage in human lymphocytes treated with doxorubicinin the Comet and fluorescence in situ hybridisation (FISH) assay. Mutat Res 390: 69-77.

41. Singh NP, Muller CH, Berger RE (2003) Effects of age on DNA double strand breaks and apoptosis in human sperm. Fertil Steril 18: 1420-1430.

42. Sega GA (1976) Molecular dosimetry of chemical mutagens. Measurement of molecular dose and DNA repair in mammalian germ cells. Mutat Res 38: 317 326.

43. Sega GA, Generoso EE (1990) Measurement of DNA breakage in specific 
Citation: Rocco L, Peluso C, Cesaroni F, Morra N, Cesaroni D, et al. (2012) Genomic Damage in Human Sperm Cells Exposed In Vitro to Environmental Pollutants. J Environment Analytic Toxicol 2:117. doi:10.4172/2161-0525.1000117

Page 7 of 7

germ-cell stages of male mice exposed to acryl amide, using an alkaline-elution procedure. Mutat Res 242: 79-87.

44. Shamsi MB, Kumar R, Dada R (2008) Evaluation of nuclear DNA damage in human spermatozoa in men opting for assisted reproduction. Indian J Med Res 127: $115-123$

45. Delbes G, Hales BF, Robaire B (2010) Toxicants and human sperm chromatin integrity. Mol Hum Reprod 16: 14-22.

46. Sailer BL, Jost LK, Everson DP (1995) Mammalian sperm DNA susceptibility to in situ denaturation associated with the presence of DNA strand breaks as measured by the terminal deoxynucleotidyl transferase assay. J Androl 16: 8087.

47. Smith A, Haaf T (1998) DNA nicks and increased sensitivity of DNA to fluorescence in situ end labelling during functional spermiogenesis. Biotechniques 25: 496-592.
48. Payne JF, Raburn DJ, Couchman GM, Price TM, Jamison MG, et al. (2005) Redefining the relationship between sperm deoxyribonucleic acid fragmentation as measured by the sperm chromatin structure assay and outcomes of assisted reproductive techniques. Fertil Steril 84: 356-364.

49. Sakkas D, Alvarez JG (2010) Sperm DNA fragmentation: mechanisms of origin impact on reproductive outcome, and analysis. Fertil Steril 93: 1027-1036.

50. Aitken RJ, De luliis GN, Finnie JM, Hedges A, McLachlan RI (2010) Analysis of the relationships between oxidative stress, DNA damage and sperm vitality in a patient population: development of diagnostic criteria. Hum Reprod 25 2415-2426.

51. Liu W, Li PJ, Qi XM, Zhou QX, Zheng L, et al. (2005) DNA changes in barley (Hordeum vulgare) seedlings induced by cadmium pollution using RAPD analysis. Chemosphere 61: 158-167. 